April 2008

\title{
The Prefiguration of Some Aspects of the Holocaust in the Armenian Genocide (Revisiting the Comparative Perspective)
}

Vahakn N. Dadrian

Follow this and additional works at: https://digitalcommons.usf.edu/gsp

\section{Recommended Citation}

Dadrian, Vahakn N. (2008) "The Prefiguration of Some Aspects of the Holocaust in the Armenian Genocide (Revisiting the Comparative Perspective)," Genocide Studies and Prevention: An International Journal: Vol. 3: Iss. 1: Article 7.

Available at: https://digitalcommons.usf.edu/gsp/vol3/iss1/7

This Articles is brought to you for free and open access by the Open Access Journals at Digital Commons @ University of South Florida. It has been accepted for inclusion in Genocide Studies and Prevention: An International Journal by an authorized editor of Digital Commons @ University of South Florida. For more information, please contact digitalcommons@usf.edu. 


\title{
The Prefiguration of Some Aspects of the Holocaust in the Armenian Genocide (Revisiting the Comparative Perspective)
}

\author{
Vahakn N. Dadrian \\ Zoryan Institute
}

\begin{abstract}
The field of genocide studies has been marked by a comparative tendency, while at the same time scholarship on the Holocaust has tended to focus on its singularity; the Armenian Genocide has often been treated as representing a "dress rehearsal" for the Holocaust. This article examines the parallels and commonalities, as well as the differences, between the two events, with a view to drawing them into a comparative perspective. More specifically, four major factors (vulnerability of the victim group, degradation of victims, war as opportunity, and fear of retaliation on the part of perpetrators) and three subsidiary factors (methods of extermination, disregard of economic factors, and terminological deflection) are examined with respect to both the Holocaust and the Armenian Genocide.
\end{abstract}

Keywords: Holocaust, Armenian Genocide, comparative perspective

From its very inception, genocide studies has been marked by a tendency to be infused with some elements of comparativeness, while the case of the Holocaust has benefited from a profusion of works focusing on and detailing elements of singularity. The World War I Armenian Genocide has served, in this respect, a useful purpose, especially because of its significant similarities to and certain commonalities with the Holocaust. This element of a nexus, a connecting link, was not only recognized but harnessed by Raphael Lemkin for a wide and encompassing project that ushered in the era of genocide studies. In “Totally Unofficial Man,” Lemkin wrote,

In 1915 ... I began ... to read more history to study whether national, religious, or racial groups as such were being destroyed. The truth came out after the war. In Turkey, more than 1,200,000 Armenians were put to death...After the end of the war, some 150 Turkish war criminals were arrested and interned by the British Government on the island of Malta... Then one day, I read in the newspapers that all Turkish war criminals were to be released. I was shocked. A nation that killed and the guilty persons were set free... I felt that a law against this type of racial or religious murder must be adopted by the world. ${ }^{1}$

The seminal nature of the perspective inherent in this statement is noteworthy. Lemkin is not only recognizing the reality of centrally organized mass murder but also discerning the pressing need for legal mechanisms to control such a crime, with the ultimate objective of preventing it. Unlike many earlier authors, however, Lemkin set out to pave the way for framing and eventually establishing internationally prevalent penal codes for the prevention and punishment of the crime of genocide. Central to all this legal and criminological endeavor was the quest for a solution to the ubiquitous problem of impunity attending that crime. ${ }^{2}$ The threat of punishment, to the extent that it could be made credible, was meant to serve the purpose of prevention. 
One of the foremost leaders of Zionism in Germany, Richard Lichtheim, who represented that movement in the Ottoman capital during World War I, went further when he focused on the matter of precedence. Lichtheim wrote that the Armenian experience was "the first instance of a systematic persecution in modern history, resembling Hitler's...crusade of destruction against the Jews."3 Two other experts appear to have concurred: Joseph Guttman characterized the Armenian case as "the beginnings of genocide," while Jehuda L. Wallach, a military historian from Tel Aviv, discerned "a certain parallel between the Jewish and Armenian catastrophes."5 These linkages found a legal echo in the declaration of a jurist who played a major role in the criminal prosecution of Nazi leaders at Nuremberg. Robert Kempner was chief of division, responsible for preparing the cases of these leaders; he was also assistant to Justice Robert Jackson, chief counsel for the United States. In a law-journal article dealing with the Armenian Genocide, Kempner declared that "for the first time in legal history," the principle of "human rights violations, especially genocide," was recognized. He further declared that such recognition was acted upon "without committing unauthorized intervention in the internal affairs of another country."6

In the more recent past, several noted experts on the Holocaust have expressed themselves along identical lines or in similar ways. Richard Rubenstein, for example, discerns "an eerie parallel" between the two cases. ${ }^{7}$ Stating that the Armenian Genocide "foreshadows the Holocaust," Yehuda Bauer uses the same term, "parallel."8 In a subsequent essay he again cites the Armenian case as offering "the closest parallel to the Jewish Holocaust... On this continuum of murderous behaviour, the Armenian massacres would figure nearest to the Holocaust." However, Bauer seems to have felt the need to interject a caveat: "The Turks never planned the murder of Armenians outside Turkey ... [whereas the Jews became victims of] a plan for the total physical annihilation of a people, everywhere one finds them." 9 Sharing Bauer's view of the "uniqueness" of the Holocaust, Lucy Davidowicz also grants the parallels, as evident in

the Turkish massacres of Armenians, which in their extent and horror most closely approximated the murder of European Jews... The once unthinkable "Armenian solution" became, in our time, the achievable "Final Solution," the Nazi code name for the annihilation of European Jews. ${ }^{10}$

In his classic treatise on the subject, Leo Kuper, another pioneer, after describing it as the "forgotten genocide," saw it fit to characterize the Armenian Genocide as "the precursor of the coldly calculated bureaucratic genocide"11_that is, the Holocaust. For his part, Israel Charny describes the Armenian instance as "a dress rehearsal for the Holocaust." 12 Yisrael Ring, another Israeli historian, is quoted as saying that the Armenian Genocide, "a model for recent history," in fact proved to be a "purifying precedent" for the Holocaust. ${ }^{13}$

Reference may also be made to Helen Fein, who occupies a prominent place in the galaxy of pioneers in genocide studies. Fein's basic premise, shared by many others cited above, is that unless single case studies progress to the level of comparative studies, the field of genocide studies will essentially be handicapped as a scientific discipline. This standpoint is enunciated in her magnum opus, Accounting for Genocide, through the postulate that "for over a millennium preceding their annihilation, both Jews and Armenians had been decreed by the dominant group that was to perpetrate the crime to be outside the sanctified universe of obligation." 14 As a matter of fact, the concept of the "sanctified universe of obligation" has become the very essence of Fein's overall conceptual framework in the general theory of genocide. 
The present essay is an attempt at further developing the common body of knowledge in genocide studies by exploring in more detail the comparative aspects of these two genocides. Such an attempt neither negates the very important factors that separate the two nor discounts the signal fact that the Holocaust is simply the bestknown case in the overall picture of genocide studies. As a point of departure, however, one may revert back to Fein's perspective. In her introductory chapter Fein repeatedly singles out some of the specifics of this phenomenon, which may be summed up as follows. Both victim groups (i.e., the Armenians in the Ottoman Empire and the Jews in Europe) lacked "sovereignty" and a "parent state"; hence, both were highly "vulnerable" victim groups, notwithstanding their "international affiliations," which did not compare with the protective condition afforded by a nation-state. This vulnerability was ensconced in the belittling titles_-rayah" and "alien"- that were attached to both victim groups. Similarly, both victim groups had experienced, at various levels and under different conditions, episodic "pogroms" during the nineteenth century-even though Jews were more assimilated, in terms of their involvement in political parties. Armenians stood among their neighbors very much as the Jews of Poland and Russia did; the former suffered the indignities of exclusion from the "Islamic universe," the latter of exclusion from the "Christian universe." Both victim groups became targets of a "premeditated genocide" that was coterminous with "organized state murder" involving "rational function" (i.e., "choice by the perpetrator"). Both perpetrator groups, the Nazis and the Young Turks, also "test[ed] the ground" by recourse to pre-genocidal "oppression" and "calculated violence against the victims."15

By departing from this overview of insights and observations, which appear to be conditioned by the authors' inveterate connectedness to Jewish ethnicity, the nexus to a transposed image of victimhood, it may be possible to construct a comparative perspective. In this respect, four primary factors may be designated for the further exploration of the comparative perspective: vulnerability, degradation of the victims, war as opportunity, and fear of retaliation. On a secondary level, the following subsidiary factors may be singled out for brief comment: techniques of extermination, belittling the economic factor, and terminological cover-ups and deflection.

\section{Vulnerability}

Declaring Jews "a security risk," the Nazi Foreign Ministry urged "the deportation" of all Jews residing "in Axis countries." This vulnerability, in the main, issued from the fact that the Jews were "all alone" and had "no parent state," while the "Allies refrained from intervening."16 General Wladyslaw Sikorski, president of the Conference on War Crimes held at St. James's Palace in 1942, justified the Allies' refusal to publicly acknowledge Nazi crimes against the Jews in their declaration on war crimes in January of that year by arguing that "the Jews were considered nationals of their reflective states" rather than being a distinct national group. ${ }^{17}$

In the Armenian case, we can observe a similar pattern of exploiting the vulnerability of the Armenian minority in the Ottoman Empire. Notorious in this respect is the promulgation, on 19 May/1 June 1915, of the Deportation Law, which was first proposed to the cabinet by Interior Minister Talât on 13/26 May 1915 and approved first by Grand Vizier Said Halim on 14/27 May and subsequently, and rather deviously, by the cabinet on 17/30 May (the established procedure required cabinet approval first). Article 2 of that law rendered the entire Armenian population, rather indirectly, a target of the whims of military authorities at almost all levels, who were thus given license to order deportations at the slightest hint (hissetmek) that the 
victims might be suspected of "espionage and treason." 18 The vulnerability here stems from the deliberate vagueness, imprecision, and general arbitrariness of the legislation. Talât recognized this element of license when he explicitly exhorted the Armenian parliamentary deputy Vartkes, just before the latter's arrest and subsequent murder-despite his parliamentary immunity-that he intended to take full advantage of the opportunity offered by the war to settle scores and resolve the Armenian question. ${ }^{19}$ When Henry Morgenthau, then US ambassador to Turkey, tried to intercede on behalf of the Armenians, Talât reportedly brushed him off, saying that "the fate of the Armenians" should be of "no concern of the U.S.A."20 A brief examination of the comparative aspects of this vulnerability factor affecting the fates of both victim groups is available within the framework of a legal analysis. ${ }^{21}$

\section{Degradation of the Victims}

Going back to the era of the anti-Semitic protestant leader Martin Luther, the Nazis, faithfully emulating him, proceeded to denounce the Jew as "a criminal, a thug, a beast of prey." Hitler himself referred to "a battle against a satanical power," while another top Nazi, Julius Streicher, depicted the Jews as parasites "who live by the sweat of others." Heinrich Himmler, chief of the SS and the police; Hans Frank, the overall governor of Poland; and Otto Thierack, the Nazis' minister of justice, were inclined to the view that the Jews "were a lower species of life which upon contact infected the German people with deadly disease." 22 Himmler, for his part, stated that "just because we exterminated a bacterium, we do not want, in the end, to be infected by that bacterium and die of it," while Frank often described the Jews as "lice." ${ }^{23}$ In April 1943, during a visit to Berlin by Admiral Miklos Horthy, regent of Hungary, Hitler again denounced the Jews as "tubercular bacilli." 24

Although there is a relative paucity of similar denigrations of the Armenians within the Turkish camp, one of the most ferocious of the Turkish génocidaires, Dr. Mehmed Reşid-a veterinarian by training, and the governor general of Diyarbekir province-described his Armenian victims as "microbes," posing the rhetorical question, "Isn't the duty of a doctor to destroy these microbes?"25

\section{War as Opportunity}

It is no accident that the two of the twentieth century's many genocides were consummated, with remarkable efficiency, during the two world wars (specifically, between 1942 and 1945 and in 1915-1916). Indeed, on 13 December 1942, Joseph Goebbels, the Nazi propaganda minister, declared, "At bottom ... I believe both the English and the Americans are happy that we are exterminating the Jewish riffraff." 26 Himmler and Goebbels considered the war a "unique opportunity for "Solving the problem." 27 While completing the preparations for the Auschwitz concentration camp, Himmler told Rudolf Höss, commandant of the camp, that Hitler's order for the "Final Solution" would have to be carried out because otherwise "the Jews will later destroy the German people."28

Official German documents amply confirm the same wartime opportunism with respect to the Armenian genocide. On 27 July 1915, for example, Germany's consul in Aleppo, Walter Rössler, reported to his chancellor in Berlin that the Turkish authorities were exploiting the war and their alliance with Germany to solve "the Armenian Question."29 On 10 August 1915, Erzurum's vice-consul, Max Erwin Scheubner-Richter, likewise informed the chancellor that the "Armenian question" that for decades had been occupying European diplomacy "will be solved now, during 
the war."30 The German Colonel Stange, on duty in the area of the genocidal operations, reported to his superior, Marshal Otto Liman von Sanders, that the Turks were bent on exploiting "this favorable opportunity" (diese günstige Gelegenheit) for solving the Armenian question. ${ }^{31}$ The wartime German ambassador, Count Paul von Wolff-Metternich, reported that the Turks were hiding behind the argument of "wartime exigency" to justify their atrocities (verschanzen sich hinter Kriegsnotwendigkeiten). ${ }^{32}$ In a second report, Scheubner-Richter told Berlin that the Young Turk leaders (otherwise identified as leaders of the Committee for Union and Progress, or CUP) had confided to him, as a representative of an allied power, that the wartime deportations of the Armenians were only a vehicle for the latter's ultimate eradication. ${ }^{33}$ The foremost urgency of completing the task of eradicating the Armenians during the war was given expression in a memorandum jointly signed by Talât and Enver on 2 August 1916. Forwarded to Berlin by Marine Attaché and Lt. Commander Hans Humann, this memo contained Talât's revealing exhortation to Berlin that he must bring to completion his plan of liquidating the Armenians: "The work that is to be done must be done now."34

\section{Fear of Retaliation}

Raul Hilberg maintains that the overall public rationale for the genocidal campaign against the Jews was the so-called Jewish danger. Even the Nazis' mobile killing units (Einsatzgruppen) had to contrive such rationales, although they had no need to account to anyone for their crimes-not even Reinhardt Heydrich, chief of the Reich Security Head Office. ${ }^{35}$ Himmler, in the course of an address to the general lieutenants (Gruppenführer) of the SS delivered in 1943, declared, "We had the moral right vis-àvis our people to annihilate (umzubringen) this people which wanted to annihilate us." ${ }^{36}$ On 5 February 1943, in the wake of the shattering defeat at Stalingrad, the German press was instructed to emphasize that "if we lose the war, we do not fall into the hands of some other states but will all be annihilated by world Jewry. Jewry firmly decided (fest entschlossen) to exterminate all Germans. International law and international custom will be no protection against the Jewish will for total annihilation. (totaler Vernichtungswille der Juden). ${ }^{37}$

Ismail Enver, war minister and de facto commander-in-chief of the OttomanTurkish Army during World War I, told Morgenthau that he had "greatest admiration for the intelligence and industry" of the Armenians; but, he added, "a few hundred bright Armenians [are capable of] overturning Turkish government." 38 For his part, Talât, omnipotent CUP party boss and interior minister, told the American ambassador that "no Armenian can be our friend after what we have done to them." ${ }^{39}$ Lewis Einstein, special agent at the American embassy in Constantinople (now Istanbul), reported that in a recent exchange Enver had admitted the CUP's apprehensions, saying that the CUP "fears the Armenians." 40

\section{Additional Subsidiary Factors}

\section{Techniques and Methods of Extermination}

Although the gas chambers were the principal vehicle of Nazi mass murder, other methods served as auxiliary means; these, however, should be viewed as infrequent and, therefore, as incidental rather than regular techniques. One of these was the act of burning alive (i.e., the en masse incineration of victims). In Slonim, for example, "many houses were set afire, until the entire ghetto was a mass of flames... Additional 
raiders then arrived with gasoline cans and burned the dead and wounded in the streets." 41 Moreover, following the establishment of the anti-partisan command under Erich von dem Bach Zelewski, "[the perpetrators] were thrown into the action on November 26, $1942 \ldots 1828$ Jews not counting bandits, Jews, etc., were burned in houses or dugouts." 42 Commenting on von dem Bach's role, a psychologist described him as a man

whose record of looting, arson and mass murder is equaled only by the Huns and Mongols of days past. General von dem Bach was the deputy Genghis khan of this horde. The troops which he commanded included the notorious Dirlewanger Brigade which was composed of habitual criminals... one single report... shows that, among others, 363,211 Jews were executed by these formations. ${ }^{43}$

However, Hilberg mentions an incident that depicts von dem Bach as a man weary of the psychological damage his troops were suffering as a result of these barbarities. He reportedly told Himmler,

Look at the eyes of the men in this Kommando, how deeply shaken they are! These men are finished [fertig] for the rest of their lives. What kind of followers are we training here? Either neurotics or savages! ${ }^{44}$

Such acts of immolation, however, as stated above, were quite widespread in the Armenian case; as such, they were a more or less integral part of the Armenian Genocide. Among numerous accounts available for study is the vivid eyewitness testimony of a Jewish observer, Eitan Belkind, an officer in the wartime Turkish army with duties at the headquarters of the Ottoman Fourth Army:

After a three day ride I reached the heart of Mesopotamia where I was a witness to a terrible tragedy ... The Circassian soldiers ordered the Armenians to gather thorns and thistles and to pile them into a tall pyramid... afterwards they tied all the Armenians who were there, almost five thousand souls, hand to hand, encircled them like a ring around the pile of thistles and set it afire in a blaze which rose up to heaven together with the screams of the wretched people who were burned to death by the fire... Two days later I returned to this place and saw the charred bodies of thousands of human beings. ${ }^{45}$

Colonel Ludwig Schraudenbach, German commander of the Ottoman-Turkish Fourteenth Division, operating likewise in Mesopotamia, cites in his memoirs another case of burning alive. Relaying information he had received, he writes that "children were placed between wooden planks, tied to them, and then burned to death." 46 The Swedish missionary Alma Johansson, on duty in wartime Turkey, reported that the Armenian inmates of an orphanage in Muş, along with the staff, were burned alive ("lebendig verbrannt"). ${ }^{47}$ For his part, the German physician H. Stoffels, likewise on duty in wartime Turkey, reported that on his way to the same city of Mush he saw "a large number of formerly Armenian localities, where in the churches and houses were charred and decomposed corpses of women and children" (verkohlte und verweste Frauen und Kinderleichen). ${ }^{48}$ Rafael Nogales, a Venezuelan major who had volunteered his services to the Turkish Army during World War I and held the title Inspector General reported observing, in the same area, "women and children penned up and burned alive." 49

Even more striking in this connection are authentic Turkish testimonies. Foremost among them is that of General Mehmed Vehip, commander of the Turkish Third Army, who testified before the Turkish military tribunal that prosecuted the authors of the Armenian Genocide in the aftermath of World War I. Vehip reported that 
"Armenian women and children were burnt alive in the village of Churig, located five kilometers north of Mush"; during an inspection of the area, he had seen the charred remains of the victims. ${ }^{50}$ Reference may also be made to the testimony of a Turkish military officer who, likewise, had personally observed the evidence of the holocaust in and around Muşand who ventured to identify Küçük Kâzim, the Turkish military officer who "was burning down the entire Mush valley and was annihilating the Armenians." 51

\section{Discounting the Economic Factor}

According to Hilberg, "the destruction process was oriented not to cost but to efficiency." 52 In the Nazi case, the authorities of the Ministry for Eastern Occupied Territories insisted that "economic questions should not be considered in the solution of the Jewish question." 53 A similar frame of mind can be discerned in the attitudes of the CUP leaders involved in genocidal decision making in Turkey. During an exchange with Morgenthau, for example, Talât declared, "We care nothing about the commercial loss. We have figured all that out... We don't worry about that." 54 Enver declared to the same ambassador, "Economic considerations are of no importance at this time"; the two were discussing the huge fiscal losses the Turkish economy was incurring as a result of the elimination of the Armenians. ${ }^{55}$ These considerations are confirmed by the memoirs of Halidé Edib, a nationalist and feminist Turkish writer whom Talât, particularly, held in high esteem. Edib relates some exchanges with Talât and acknowledges that, in fact, self-serving economic considerations played a paramount role in the decision to uproot the Armenians: the goal was "to end the economic supremacy of the Armenians thereby clearing the markets for the Turks and the Germans."56

\section{Terminological Deflections and Cover-Ups}

The Nazis contrived an extensive vocabulary for the express purpose of camouflaging their real goal with respect to the Jews; Hilberg's list takes up most of a page. ${ }^{57}$ The most recurrent terms are Ausschaltung ("elimination"), Aussiedlung ("resettlement"), Sondermassnahmen ("special measures"), Sonderaktionen ("special actions"), and Sonderbehandlung ("special treatment"). The Jews were "bluffed" and tricked with "registrations" and "resettlements," with "baths" and "inhalations." 58 In the Armenian case, however, the decision makers throughout confined themselves to the twin terms tehcir ("deportation") and tebdili mekân ("relocation"), deflecting attention from the covert purposes of the mechanisms of deportation and covering up the ultimate, exterminatory goal. ${ }^{59}$

\section{Conclusion}

Superseding in import and consequence all these similarities and commonalities is the overarching illegality of the origins and evolving careers of the regimes of both perpetrator groups-the type of illegality that, completely devoid of elements of responsibility and accountability, readily degenerated into lethal criminality. In the process, the functions of each state were overwhelmed by the imposition on their respective systems of the desiderata of two highly monolithic and dictatorial political parties. The subversion and ultimate criminalization of these state functions thus became the order of the day. The Reichstag fire and the Enabling Act (in February and March 1933) and the Nuremberg Laws of 1935, on the one hand, or the January 1913 Young Turk overthrow of the government and the subsequent political purges throughout the land, on the other, are the incipient initiatives of this process. The prevalence of the common pattern of substituting party authority (that of NSDAP and 
the CUP, with all their variants) for legitimate state authority is all too evident. Accordingly, the cardinal lesson to be derived from this comparative essay is that the arch determinant in cases of genocide is not the state, to whose powers and resources are generally attributed the latitude for genocidal decision making and the associated enactment, but the progressively incremental power structure of dictatorial political parties. Equally important is the fact of the illicit capture of constitutional authority and its transfer from the legitimate state to a political party that is mobilized with highly secretive and radical designs, some of them exterminatory; such illicit action is capable of providing the requisite dynamics for genocidal radicalism. Among the many ways in which state functions are thus subverted, perhaps the most consequential is that many of these functions are reduced and instrumentalized for the hidden goals of the party. In other words, in addition to subverting its functions, the quasi-omnipotent party specifically aims to reduce the state to a level of optimal subservience to the party. This has been confirmed by wartime Turkish general Vehip. In one way or another, consequently, the state ultimately becomes complicit in the series of crimes that inevitably ensues. This is a process that might be called outcome-oriented, radical, and deadly task performance. Such an outcome was foreseen by Aristotle when he declared, nearly twenty-five centuries ago, that "when separated from law and justice man is the worst of all animals." 60

\section{Notes}

1. Steven Leonard Jacobs and Samuel Totten, "Totally Unofficial Man," in Pioneers of Genocide Studies, ed. Samuel Totten and Steven Leonard Jacobs, 365-99 (New Brunswick, NJ: Transaction Publishers, 2002), 371. When separating singularity from the concept of "uniqueness," Leo Kuper, a pioneer of genocide studies, is quoted in the same work as saying that "the weakening of empathy for other groups in their affliction has always seemed to me a betrayal of traditional Jewish concern and compassion for the suffering of others." Kuper goes on to state that such a sense of "uniqueness" can be "combined with a heightened concern for the suffering of others." Ibid., 469. Lemkin's original unpublished manuscript is housed in the Raphael Lemkin Papers, Manuscripts and Archives Division, New York Public Library. In addition. the American Jewish Historical Society has a Raphael Lemkin collection containing "several rare documents" from 1915-1919 and 1946-1948, Box 9, Folder 23. Many of these pieces are discussed in the special issue of Journal of Genocide Research (volume 7, no. 4, December 2005) dedicated to the life and work of Raphael Lemkin. Armenian sources aver that Lemkin, on several occasions, emphasized the special impact the horrors of the Armenian Genocide had on him. In a 1959 article, he wrote that "the sufferings of the Armenian men, women and children thrown into the Euphrates River or massacred on the way to Deir Zor have prepared the way for the adoption for the Genocide Convention by the United Nations ... one million Armenians died, but a law against the murder of peoples was written with the ink of their blood and the spirit of their sufferings." Raphael Lemkin, "The Armenian Stake in the Genocide Convention," Hairenik Weekly, 1 January 1959: 3.

2. Lemkin, in this respect, was not far off the mark. The convention he refers to here was preceded by two principal resolutions issued by the United Nations. One of them, Resolution 95(1) of 11 December 1946, states that the UN General Assembly "affirms the principle of international law recognized by the Charter of the Nuremberg Tribunal and the judgment of Tribunal." But article 6(c) of that charter, which embraced the legal norm of "crimes against humanity," was, in the main, derived and adopted from a declaration made by the Allies on 24 May 1915 with respect to the initiation of the wartime Armenian Genocide, which they branded as a "crime against humanity." This fact is acknowledged by the authoritative UN War Crimes Commission, History of the United Nations War Crimes Commission and the Development of the Laws of War (London: HMSO, 1948), 26, 25, 191, 194, 196-97. 
3. Richard Lichtheim, Rückkehr (Stuttgart: Deutsche-Verlags-Anstalt, 1970), 287, 341. Unless otherwise stated, all translations into English are my own.

4. Joseph Guttman, The Beginnings of Genocide: A Brief Account of the Armenian Massacres in World War I (New York: Armenian National Council of America, 1948). This document was first published in Yiddish in Israel.

5. Jehuda L. Wallach, Anatomic einer Militärhilfe. Die preussisch-deutschen Militärmissionen in der Türkei 1835-1919 (Düsseldorf: Droste, 1972), 207.

6. Robert Kempner, "Vor 60 Jahren vor einem deutschen Schwurgericht. Der Völkermord an den Armeniern," Recht und Politik 3 (1980): 162-69, 167.

7. Richard Rubinstein, The Age of Triage (Boston: Beacon Press, 1993), 13, 142-44.

8. Yehuda Bauer, A History of the Holocaust (New York: F. Watts, 1982), 57-58.

9. Yehuda Bauer, "Essay: On the Place of Holocaust in History," Holocaust and Genocide Studies 2 (1987): 209-20, 213, 215, 217. The latter claim-that Armenians escaped annihilating massacres "outside of Turkey"-is simply inaccurate; it betrays the general prevalence of incomplete knowledge of the wide-ranging dimensions of the Armenian Genocide, whose murderous tentacles reached out into Armenia in the Transcaucasus when, in the fall of 1920, Turkish general Kâzı̌m Karabekir's 15th Army Corps (the former 9th Army) invaded the infant Republic of Armenia. Embedded in its constituent 3rd, 9th, and 11th Caucasian Divisions, and additionally the 12th Division, were five military officers. As leading Special Organization (SO) taskmasters, these officers had already played a major role in the organization and implementation of the wartime genocide. Colonel Seyfi (Düzgören), Colonel Deli Halit, and General Halil (Kut) were assisted by Filibeli Hilmi, who bore the title of Inspector of the Young Turk ruling party of Ittihad and had been the wartime assistant to Dr. Bahaeddin Şakir, one of the principal architects of genocide. Additionally, two bloodthirsty SO henchmen, Ebuhintli Cafer and Topal Osman, actively participated in the ensuing post-World War I massacres in Armenia itself. According to Soviet statistics, the Armenian victims included some 60,000 murdered and 30,000 wounded. Moreover, preceding these atrocities were the massacres in Baku, to which some 25,000 Armenians fell victim between 15 and 17 September 1918. What is so significant about this particular episode is the pivotal role that Şakir is known to have played by coming to Baku from Turkey for the special purpose of organizing the massacres. Vahakn N. Dadrian, The History of the Armenian Genocide: Ethnic Conflict from the Balkans to Anatolia to the Caucasus, 7th ed (New York: Berghahn Books, 2007), 360, 361-69. For Dr. Şakir's special mission to Baku in the fall of 1918 and the ensuing massacres, see 429-31.

10. Lucy S. Dazidowicz, The Holocaust and the Historians (Cambridge: Harvard University Press, 1986), 13.

11. Leo Kuper, Genocide: Its Political Use in the Twentieth Century (New Haven, CT: Yale University Press, 1982), 105.

12. Israel W. Charny, "Genocide: The Ultimate Human Rights Problem," Social Education 1 (1986): 447-54, 452.

13. Yisrael Ring, Are There Laws in Genocide? (Tel Aviv: Sifiat Poalim, 1987), 49 [in Hebrew], quoted in Yair Auron, The Banality of Indifference: Zionism and the Armenian Genocide (New Brunswick, NJ: Transaction Publishers, 2000), 16-17.

14. Helen Fein, Accounting for Genocide: National Responses and Jewish Victimization during the Holocaust (New York: Free Press, 1979), 4.

15. Ibid., 4-11.

16. Raul Hilberg, The Destruction of European Jews (Chicago: Quadrangle Books, 1961), 656.

17. Fein, Accounting for Genocide, 169.

18. Muammer Demirel, Birinci Dünya Harbinde Erzurum Ve Çevresinde Ermeni Hareketleri 1914-1918 (Ankara: General Staff Publications, 1996), 54-55.

19. Johannes Lepsius, Der Todesgang des Armenischen Volkes (Berlin: Temple, 1930), 195-96.

20. Henry Morgenthau, Ambassador Morgenthau's Story (Garden City, NY: Doubleday, 1918), 330. 
21. Vahakn N. Dadrian, "The Historical and Legal Interconnections between the Armenian Genocide and the Jewish Holocaust: From Impunity to Retributive Justice," Yale Journal of International Law 23 (1998): 517-19; Dadrian, History of the Armenian Genocide, 395-401.

22. Hilberg, Destruction, 12.

23. Ibid., 11, 12 .

24. Ibid., 524.

25. Vahakn N. Dadrian, "The Role of Turkish Physicians in the World War I Genocide of Ottoman Armenians," Holocaust and Genocide Studies 1 (1986): 169-92, 175.

26. The Goebbels Diaries, 1942-1943, ed. and trans. Louis P. Lochner (Garden City, NY: Doubleday, 1948), 241.

27. Hilberg, Destruction, 266.

28. Ibid., 564.

29. PA-AA/R14087, A53a/1915/4563, report from Walter Rössler, German Consul in Aleppo, to Chancellor Bethmann Hollweg, dated 27 July 1915, trans. Linda Struck, http:// www.armenocide.de/armenocide/armgende.nsf/3a4b0a224f485c26c1256ad8001005f2/ 7840606dbef28037c12568f30059b1cf?OpenDocument (accessed 7 January 2008).

30. PA-AA/R14088, 1915-A-28584, Report from Max Erwin Scheubner-Richter, Acting Vice Consul, in Erzerum, to Chancellor Bethmann Hollweg, dated 10 August 1915, trans. Linda Struck, http://www.armenocide.de/armenocide/armgende.nsf/3a4b0a224f485c26c1256ad 8001005f2/bdd0dd438e772a37c12568f30059b1df?OpenDocument (accessed 7 January 2008)

31. PA-AA/BoKons./Band 170, Militär Mission J. Nr. 3841, Report from Colonel Stange to the German Military Mission in Constantinople, dated 23 August 1915, trans. Linda Struck, http://www.armenocide.de/armenocide/armgende.nsf/3a4b0a224f485c26c1256ad8001005f2/ 52e6daece2fb4eecc12568f30059b1f4?OpenDocument (accessed 7 January 2008).

32. PA-AA/R14089, 1915-A-36184, Report from Wolff-Metternich, Ambassador in Extraordinary Mission in Constantinople, to Chancellor Bethmann Hollweg, dated 7 December 1915, trans. Linda Struck, http://www.armenocide.de/armenocide/armgende. nsf/3a4b0a224f485c26c1256ad8001005f2/ f860f1a7cd668e3bc1256934006c94e8?OpenDocument (accessed 7 January 2008).

33. PA-AA/R14094, 1916-A-33457, Report from Max Erwin Scheubner-Richter, Acting Vice Consul, in Erzerum, to Chancellor Bethmann Hollweg, dated 4 December 1916, trans. Vera Draack, http://www.armenocide.de/armenocide/armgende.nsf/3a4b0a224f485c26c1256ad8 001005f2/3ae55a79b55f09b4c12568f30059b2be?OpenDocument (accessed 7 January 2008).

34. Quoted in Ulrich Trumpener, Germany and the Ottoman Empire, 1914-1918 (Princeton, NJ: Princeton University Press, 1968), 127.

35. Hilberg, Destruction, 216

36. Ibid., 647.

37. Ibid., 655.

38. Morgenthau, Ambassador, 345, 347.

39. Ibid., 339.

40. Lewis Einstein, Inside Constantinople: A Diplomatic Diary (New York: Dutton \& Co., 1918), 126 (this statement is reported in the diary entry for 19 June 1915).

41. Hilberg, Destruction, 249.

42. Ibid., 251.

43. L Alexander, "War Crimes and Their Motivation: The Social-psychological Structure of the SS and the Criminalization of Society," Journal of Criminal Law, Criminology and Police Science 39 (1948): 176-94, 181-83, 187-92.

44. Hilberg, Destruction, 218; also 646.

45. Quoted in Auron, Banality of Indifference, 181, 183.

46. Ludwig Schraudenbach, Muharebe [Warfare] (Berlin: Drei Masken, 1925), 351-52.

47. AA Turkei, R14097, report, 1 October 1917.

48. Austrian Foreign Ministry Archives, 12 Türkei/380, report, 26 May 1917. 
49. Rafael de Nogales, Four Years Beneath the Crescent, trans. Muna Lee (New York: Scribner's Son, 1926), 135.

50. Quoted in Vahakn N. Dadrian, "Children as Victims of Genocide: The Armenian Case," Journal of Genocide Research 5 (2003): 421-37, 431-32.

51. Ibid., 432.

52. Hilberg, Destruction, 645.

53. Ibid., 646.

54. Morgenthau, Ambassador, 338.

55. Ibid., 348.

56. Halidé Edib Adivar, Memoirs of Halidé Edib (New York: Century Co., 1926), 386-87.

57. Hilberg, Destruction, 216.

58. Ibid., 667.

59. For more details on this topic see Vahakn N. Dadrian, "The Convergent Aspects of the Armenian and Jewish Cases of Genocide: A Reinterpretation of the Concept of Holocaust," Holocaust and Genocide Studies 3 (1988): 151-69.

60. Aristotle, The Politics, trans. Benjamin Jowett and Thomas Twining (1959), book 1, ch. 2, 6 . 